Sentralisasi Volume 8 ( 2 ) hal : 86 - 98 | 2019 Pengaruh Perputaran Modal Kerja, Perputaran Persedian Dan Arus Kas...

Doi (https://doi.org/10.33506/sl.v8i2.448)

Pertiwi Sriwalet

\title{
Pengaruh Perputaran Modal Kerja, Perputaran Persediaan Dan Arus Kas Terhadap Rasio Lancar Pada Perusahaan Makanan Dan Minuman Yang Terdaftar Di Bursa Efek Indonesia Periode 2014 -2017
}

\section{Pertiwi Sriwalet $^{1}$, Yolanda Ernawati Sianturi ${ }^{2}$, Ronald Hasudungan Rajaguguk ${ }^{3}$, Mas Intan Purba ${ }^{4}$}

${ }^{1,2,3,4}$ Fakultas Ekonomi, Program Studi Akuntansi, Universitas Prima Indonesia

Email : Pertiwihwang@gmail.com

Direvisi: 29 Mei 2019 Dipublikasikan: 30 Juni 2019

\begin{abstract}
Abstrak
Penelitian ini bertujuan untuk menguji dan menganalisis pengaruh perputaran modal kerja, perputaran persediaan dan arus kas baik secara parsial maupun simultan terhadap rasio lancar yang terdaftar di Bursa Efek Indonesia Periode 2014 - 2017. Metode pengumpulan data yang di gunakan adalah metode kuantitatif. Jenis penelitian ini menggunakan pendekatan deskriptif kuantitatif. Teknik pengumpulan data dengan dokumentasi. Teknik yang digunakan dalam pengambilan sampel adalah Purposive Sampling, sehingga sampel sebanyak 11 perusahaan. Model analisis dalam peneliian ini adalah analisis persamaan regresi linier berganda, koefisien determinasi hipotesis, uji $\mathrm{F}$ dan uji T. Hasil penelitian secara parsial menunjukkan bahwa perputaran modal kerja berpengaruh negatif signifikan terhadap rasio lancar, perputaran persediaan tidak berpengaruh terhadap rasio lancar, arus kas berpengaruh negatif signifikan terhadap rasio lancar. Sedangkan secara simultan perputaran modal kerja, perputaran persediaan dan arus kas berpengaruh positif dan signifikan terhadap rasio lancar. Hasil analisis koefisien determinasi diperoleh nilai adjusted $\mathrm{R}$ Square sebesar 0.867. Hal ini menunjukkan bahwa $86.7 \%$ variabel rasio lancar dapat digunakan oleh variabel perputaran modal kerja, perputaran persediaan dan arus kas sedangkan sisanya sebesar $13.3 \%$ merupakan variabel lain seperti penjualan, TATO, piutang, ROA yang tidak dijelaskan dalam peneltian ini.
\end{abstract}

Kata Kunci : Perputaran Modal Kerja, Perputaran Persediaan, Arus Kas dan Rasio Lancar

\begin{abstract}
This study aims to text and analyze the effect of Working Capital Tunover, Inventory Turnover and Cash Flow turnover both partially and simultaneously on the Current Ratio listed on the Indonesia Stock Exchange for the period of 2014 - 2017. Data collection methods used are quantitative methods. This type of research uses a quantitative descriptive approach. Technique of collecting data with documentation. The technique used in sampling is purposive sampling, so that a sample of 11 companies. The analysis model in this study is the analysis of multiple linear regression equations, hypothesis determination coefficient, $F$ test and T test. The results of the research partially show that Working Capital Tunover has a significant negative effect on the Current Ratio, Inventory Turnover has no effect on Current Ratio, Cash Flow has a negative effect significant to Current Ratio. While simultaneously Working Capital Turnover, Inventory Turnover and Cash Flow have a positive and significant effect on the Current Ratio. The results of the coefficient of determination analysis obtained an adjusted $R$ Square value of 0.867. This shows that $86.7 \%$ of the Current Ratio variable can be used by the Working Capital
\end{abstract}


Sentralisasi Volume 8 ( 2 ) hal : 86 - 98 | 2019 Pengaruh Perputaran Modal Kerja, Perputaran Persedian Dan Arus Kas...

Doi (https://doi.org/10.33506/sl.v8i2.448)

Pertiwi Sriwalet

Tunover, Inventory Turnover, Cash Flow variables while the remaining 13.3\% is another variable such as sales, TATO, accounts receivable, ROA which is not explained in this research.

\section{Keywords : Working Capital Turnover, Inventory Turnover, Cash Flow and Current Ratio.}

\section{Pendahuluan}

Tingkat likuiditas sebuah organisasi perusahaan biasanya dijadikan sebagai salah satu tolak ukur untuk pengambilan keputusan orang-orang yang berkaitan dengan perusahaan. Beberapa pihak yang biasanya terkait dengan tingkat likuiditas suatu perusahaan yaitu pemegang saham, penyuplai bahan baku, manajemen perusahaan, kreditor, konsumen, pemerintah, lembaga asuransi dan lembaga keuangan. Semakin tinggi tingkat likuiditas sebuah organisasi perusahaan, maka semakin baik pula kinerja perusahaan tersebut. Sebaliknya, semakin rendah tingkat likuiditas sebuah organisasi perusahaan, maka semakin buruklah kinerja perusahaan tersebut. Perusahaan yang memiliki tingkat likuiditas yang tinggi biasanya lebih berpeluang mendapatkan berbagai macam dukungan dari pihak-pihak luar seperti lembaga keuangan, kreditur, dan juga pemasok bahan baku.

Rasio lancar merupakan salah satu rasio likuiditas, biasanya digunakan sebagai alat untuk mengukur keadaan likuiditas suatu perusahaan, dan juga merupakan petunjuk untuk dapat megetahui dan menduga seberapa besar kemampuan perusahaan untuk memenuhi kewajiban keuangannya. Rasio lancer yang tinggi maka makin baiklah posisi para kreditor, oleh karena terdapat kemungkinan yang lebih besar bahwa utang perusahaan itu akan dapat dibayar pada waktunya. Hal ini terutama berlaku bila pimpinan perusahaan menguasai pospos modal kerja dengan ketat atau dengan semestinya. Di lain pihak ditinjau dari sudut pemegang saham suatu rasio lancar yang tinggi tidak selalu paling menguntungkan, terutama bila terdapat saldo kas yang kelebihan dan jumlah piutang dan persediaan adalah terlalu besar. Suatu rasio lancar yang rendah lebih banyak mengandung risiko dari pada suatu rasio lancar yang tinggi, akan tetapi rasio lancar yang rendah menunjukkan pimpinan perusahaan menggunakan aktiva lancar sangat efektif. Terdapat saldo kas yang kelebihan dan jumlah piutang dan persediaan adalah terlalu besar. Suatu rasio lancer yang rendah lebih banyak mengandung risiko dari pada suatu rasio lancar yang tinggi, akan tetapi rasio 
Sentralisasi Volume 8 ( 2 ) hal : 86 - 98 | 2019 Pengaruh Perputaran Modal Kerja, Perputaran Persedian Dan Arus Kas...

Doi (https://doi.org/10.33506/sl.v8i2.448)

Pertiwi Sriwalet lancar yang rendah menunjukkan pimpinan perusahaan menggunakan aktiva lancar sangat efektif.

Perusahaan yang mampu menghasilkan nilai tambah atau keuntungan yang sustainable (berkelanjutan) adalah perusahaan yang mampu memanfaatkan modal kerjanya secara efekif dan efisien. Kesalahan atau tidak efektifnya pengelolaan modal kerja biasanya menyebabkan menurunnya performa operasional perusahaan. Modal kerja yang selalu dalam keadaan berputar membuat perusahaan harus mengukur efisiensi kinerja penggunaan modal kerja perusahaan dalam menghasilkan suatu pendapatan maka diperlukan suatu analisis yaitu analisis perputaran modal kerja. Perputaran modal kerja diharapkan terjadi dalam jangka waktu yang relatif pendek, sehingga modal kerja yang ditanamkan cepat kembali. Periode perputaran modal kerja dimulai dari kas diinvestasikan dalam komponen-komponen modal kerja sampai saat dimana kembali lagi menjadi kas. Pengelolaan modal kerja merupakan hal yang sangat penting dalam perusahaan karena merupakan salah satu alat ukur yang dapat digunakan untuk menyelesaikan masalah likuiditas perusahaan. Semakin tinggi perputaran modal kerja berarti likuiditas yang dimiliki perusahaan semakin rendah, dan begitupun dengan sebaliknya semakin rendah perputaran modal kerja berarti likuiditas yang dimiliki perusahaan semakin tinggi. Unsur aktiva lancar jumlahnya adalah persediaan. Persediaan merupakan unsur yang aktif dalam operasi perusahaan yang secara terus-menerus diperoleh, diubah, dan kemudian dijual kepada konsumen. Dengan adanya pengelolaan persediaan yang baik, maka perusahaan dapat segera mengubah persediaan yang tersimpan menjadi laba melalui penjualan yang kemudian bertransformasi menjadi kas atau piutang. Semakin tingginya tingkat perputaran persediaan menyebabkan perusahaan semakin cepat dalam melakukan penjualan barang dagang sehingga semakin cepat pula bagi perusahaan dalam memperoleh dana baik dalam bentuk uang tunai (kas) ataupun piutang. besar kecilnya aktiva lancar tersebut nantinya akan turut mempengaruhi rasio lancarnya.

Kas merupakan unsur aktiva yang paling lancar atau dengan kata lain kas merupakan modal kerja yang paling likuid, sehingga dengan ketersediaan kas yang cukup maka perusahaan tidak akan kesulitan dalam memenuhi kewajiban yang jatuh tempo. informasi tentang arus kas suatu perusahana berguna bagi para pemakai laporan keuangan sebagai dasar untuk menilai kemampuan perusahaan dalam menghasilkan kas dan setara kas, dan menilai kebutuhan perusahaan untuk 
Sentralisasi Volume 8 ( 2 ) hal : 86 - 98 | 2019 Pengaruh Perputaran Modal Kerja, Perputaran Persedian Dan Arus Kas...

Doi (https://doi.org/10.33506/sl.v8i2.448)

Pertiwi Sriwalet menggunakan arus kas tersebut. Arus kas merupakan jiwa bagi setiap perusahaan dan fundamental bagi eksistensi sebuah perusahaan serta menunjukkan dapat tidaknya sebuah perusahaan membayar semua kewajibannya.

Perputaran modal kerja yang terdapat pada tabel fenomena memperlihatkan pada umumnya menunjukkan peningkatan dimana akan diikuti dengan likuiditas yang ikut meningkat, akan tetapi pada PT Akasha Wira International,Tbk. terjadi penurunan perputaran modal kerja pada tahun 2014-2015 dan hal itu diikuti dengan peningkatan likuiditas. Hal itu bertolak belakang dengan teori. Persediaan pada umumnya apabila semakin tinggi perputarannya, maka akan semakin tinggi juga likuiditas. Namun pada PT Ultra Jaya Milk Industry \& Trading Company,Tbk. di tahun 2016-2017 terjadi penurunan perputaran persediaan dan hal itu diikuti dengan peningkatan likuiditas. Begitu juga dengan arus kas, pada umumnya menunjukkan peningkatan dan diikuti dengan peningkatan likuiditas, namun hal berkebalikan terjadi pada PT Mayora Indah,Tbk. di tahun 2015-2016. Makanan dan minuman merupakan bagian dari perusahaan manufaktur yang terdaftar di Bursa Efek Indonesia dengan jumlah perusahaan paling banyak yaitu lima belas perusahaan, dibandingkan dengan kategori perusahaan lain yang termasuk sektor manufaktur, perusahaan makanan dan minuman paling tahan terhadap krisis dibandingkan dengan sektor lainnya, sebab dalam kondisi krisis ataupun tidak produk pada perusahaan makanan dan minuman tetap dibutuhkan. Sektor consumer goods adalah sektor yang memiliki prospek paling menarik di bursa saham, karena sektor ini adalah sektor yang paling tahan banting saat menghadapi krisis dibandingkan dengan sektor-sektor bisnis lainnya. Sektor konsumsi akan selalu dibutuhkan banyak orang. Selama perusahaan dikelola management yang baik tidak rajin berhutang dan menghabiskan uang perusahaan maka sektor konsumsi ada peluang besar untuk selalu bertumbuh. Dalam keadaan krisis konsumen akan membatasi konsumsinya dengan memenuhi kebutuhan dasar dan mengurangi kebutuhan barang sekunder. Selain itu bahan baku yang digunakan untuk membuat produk pada perusahaan makanan dan minuman mudah untuk diperoleh. Pada tahun 2017 pertumbuhan perusahaan makanan dan minuman mencapai 9,23\% atau naik dari 2016 yang sebesar 8,46\%. Selain itu kontribusi industri mamin ke pbd juga cukup besar.industri makanan dan minuman kontribusi ke pdb non migas 34,33\%. Pertumbuhan industri makanan dan minuman dan minuman pada tahun 2017 mencapai sebear 9,23\%, mengalami peningkatan bila dibandingkan dengan tahun 2016 sebesar 8,46\%. 
Sentralisasi Volume 8 ( 2 ) hal : 86 - 98 | 2019 Pengaruh Perputaran Modal Kerja, Perputaran Persedian Dan Arus Kas...

Doi (https://doi.org/10.33506/sl.v8i2.448)

Pertiwi Sriwalet

Pertumbuhan industri makanan dan minuman membantu pemerataan ekonomi karena mayoritas pelakunya di sektor ukm. Hal ini menunjukan industri mempunyai peran yang besar dalam pertumbuhan ekonomi indonesia. Ekspor produk mamin termasuk minyak kelapa sawit di 2017 memiliki neraca perdagangan yang positif dibanding 2016. Angka tersebut mencapai us $\$ 31,7$ miliar.

Penelitian ini bertujuan, 1) untuk menguji dan menganalisis pengaruh perputaran modal kerja terhadap rasio lancer pada perusahaan makanan dan minuman yang terdaftar di bursa efek indonesia periode 2014-2017. 2) untuk menguji dan menganalisis pengaruh perputaran persediaan terhadap rasio lancar pada perusahaan makanan dan minuman yang terdaftar di bursa efek indonesia periode 2014-2017. 3) untuk menguji dan menganalisis pengaruh arus kas terhadap rasio lancar pada perusahaan makanan dan minuman yang terdaftar di bursa efek indonesia periode 2014-2017. 4) untuk menguji dan menganalisis pengaruh perputaran modal kerja, perputaran persediaan dan arus kas terhadap rasio lancar pada perusahaan makanan dan minuman yang terdaftar di bursa efek indonesia periode 2014-2017.

\section{Metode Penelitian}

Penelitian ini bersifat deskriptif eksplanatory untuk mengetahui hubungan atau pengaruh antar variabel. Penelitian ini menggunakan data sekunder yang bersifat empiris, dimana data yang diperoleh dari dokumen dengan cara browsing pada situs resmi Bursa Efek Indonesia. Sedangkan pendekatan penelitian yang digunakan adalah pendekatan kuantitatif, dimana pendekatan ini digunakan untuk meneliti pada populasi atau sampel tertentu, teknik pengambilan sampel pada umumnya dilakukan secara random, pengumpulan data menggunakan instrumen penelitian, analisis data bersifat kuantitatif atau statistik dengan tujuan untuk menguji hipotesis yang telah ditetapkan. Adapun populasi dari penelitian ini adalah perusahaan yang bergerak dibidang makanan dan minuman di Bursa Efek Indonesia periode 2014-2017 yang berjumlah 16 perusahaan. Teknik penarikan sampel purposive sampling teknik melakukan sampel dengan pertimbangan tertentu.

Teknik pengumpulan data yang digunakan dalam penelitian ini adalah dengan mengunakan teknik dokementasi. Data yang digunakan dalam penelitian ini dikumpulkan dengan mendokumentasi dari laporan keuangan keuangan perusahaan makanan dan 
Sentralisasi Volume 8 ( 2 ) hal : 86 - 98 | 2019 Pengaruh Perputaran Modal Kerja, Perputaran Persedian Dan Arus Kas...

Doi (https://doi.org/10.33506/sl.v8i2.448)

Pertiwi Sriwalet minuman di Bursa Efek Indonesia. Penelitian ini menggunakan uji asumsi klasik yaitu uji normalitas, uji multikonearitas, uji heterokedastisitas, dan uji autokorelasi. Uji hipotesis yaitu uji t (secara parsial), uji F (secara simultan), dan koefisien determinasi.

\section{Hasil Penelitian}

\section{Uji Normalitas}

Pengujian ini bertujuan untuk menguji apakah model regresi, variabel pengganggu atau residual memiliki distribusi normal. berikut ini dapat dilihat grafik hasil penelitian data yang telah diolah dengan pengujian SPSS versi 20 adalah sebagai berikut :

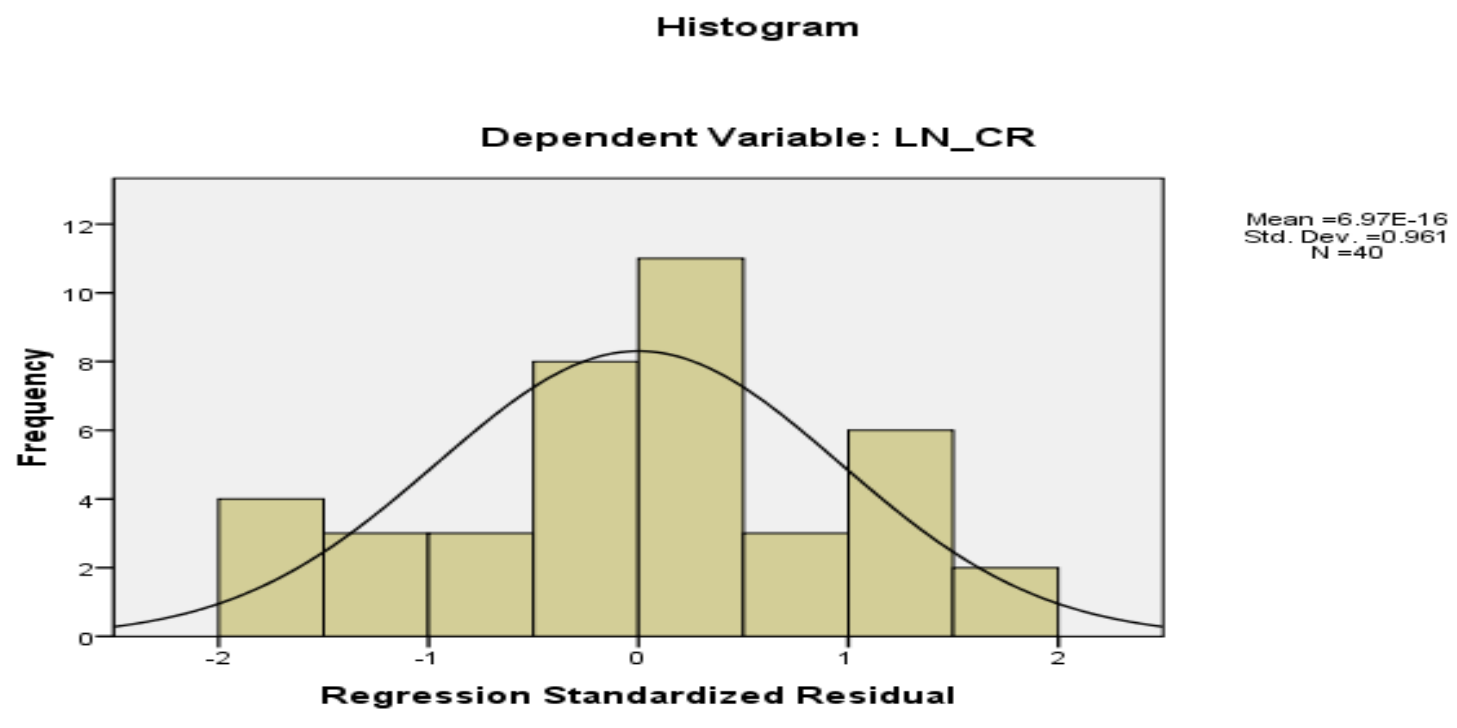

\section{Gambar 1 Normalitas Histogram}

Pada gambar diatas diketahui bahwa grafik histogram menunjukkan garis kurva cenderung simetri (U) maka dapat dikatakan data berdistribusi normal. 


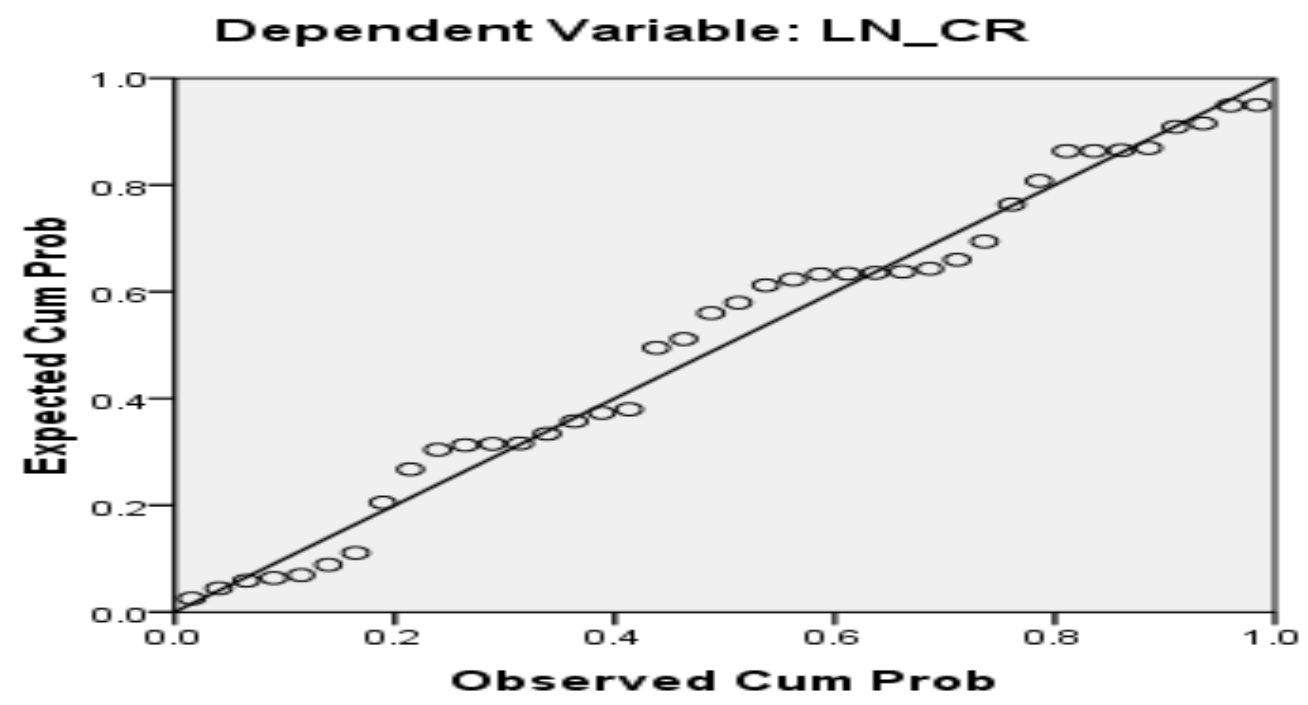

Gambar 2 Normalitas P-plot of regresi

Pada grafik normal plot terlihat titik-titik menyebar mendekati garis diagonal sehingga dapat dilakukan data telah berdistribusi normal, sehinnga layak digunakan. Salah satu uji statistik yang dapat digunakan untuk menguji normalitas residual adalah uji statistik. Kolmogorov smornov (K-S). uji (K-S) kriteria pengujinya adalah sebagai berikut: Jika nilai signifikansi $<0,05$ maka distribusi data residual tidak normal

Jika nilai signifikansi > 0,05 maka data residual berdistribusi normal

\section{Uji Multikonieritas}

Ada tidaknya masalah multikonieritas dalam regresi dapat dilihat dengan nilai VIF (variance inflactor factor) dan nilai toleransi. Uji multikolinearitas bertujuan untuk menguji apakah model regresi ditemukan adanya korelasi antar variabel bebas (independen). Model regresi yang baik seharusnya tidak terjadi korelasi di antara variabel independen. Dalam hal ini ketentuannya adalah :

Jika VIF $<10$ maka tidak terjadi multikolineritas, Jika VIF $>10$ maka terjadi multikolineritas, Jika Tolerance > 0,10 maka tidak terjadi multikolineritas, Jika Tolerance $<0,10$ maka terjadi multikolineritas. 
Sentralisasi Volume 8 ( 2 ) hal : 86 - 98 | 2019 Pengaruh Perputaran Modal Kerja, Perputaran Persedian Dan Arus Kas...

Doi (https://doi.org/10.33506/sl.v8i2.448)

Pertiwi Sriwalet

Tabel 1 Multikolineritas

Coefficients $^{\mathbf{a}}$

\begin{tabular}{llcc}
\hline \multirow{2}{*}{ Model } & \multicolumn{2}{c}{ Collinearity Statistics } \\
\cline { 3 - 4 } & & Tolerance & VIF \\
\hline 1 & (Constant) & & \\
& LN_WCTO & .581 & 1.722 \\
& LN_ITO & .893 & 1.120 \\
LN_ARUSKA & .614 & 1.629 \\
S & & \\
\hline
\end{tabular}

a. Dependent Variable: LN_CR

Berdasarkan tabel diatas uji multikoneritas diatas nilai VIF dan tolerance menunjukkan bahwa semua variabel yang digunakan dalam penelitian ini nilai VIF lebih kecil dari 10 dan tolerance yang mendekati 0,10 dapat disimpulkan bahwa tidak ada multikolonieritas antara variabel independen dalam model regresi tersebut.

\section{Uji Heterokedastisitas}

Bertujuan untuk menguji apakah dalam model regresi terjadi ketidaksamaan varian dari residual suatu pengamatan ke pengamatan lain. Hal seperti ini juga disebut sebagai homokedastisitas dan jika berbeda disebut heterokedastisitas atau tidak terjadi heterokedastisitas. 
Sentralisasi Volume 8 ( 2 ) hal : 86 - 98 | 2019 Pengaruh Perputaran Modal Kerja, Perputaran Persedian Dan Arus Kas...

Doi (https://doi.org/10.33506/sl.v8i2.448)

Pertiwi Sriwalet

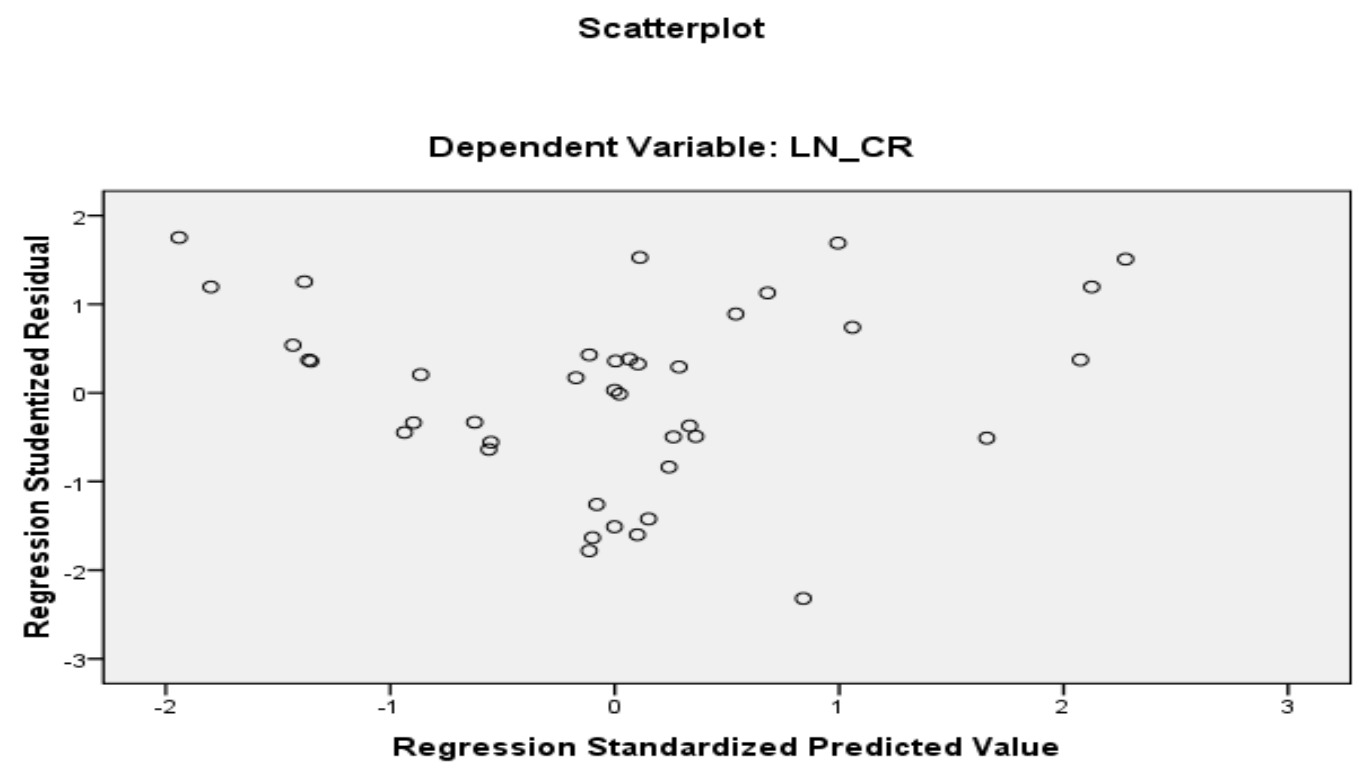

Gambar 3 Heterokedastisitas

Berdasarkan gambar grafik Scatterplot terlihat bahwa titik-titik menyebar secara acak baik diatas maupun dibawah angka nol (0) pada sumbu Y, tidak berkumpul disatu tempat, sehingga dari grafik scatterplot dapat disimpulkan bahwa tidak terjadi heteroskedastisitas pada model regresi.

\section{Regresi Berganda}

Regresi berganda digunakan dalam penelitian ini bertujuan untuk mengetahui bagaimana variabel dependen dipengaruhi variabel independen bila variabel independen sebagai factor prediktor. Berikut hasil pengolahan data dengan menggunakan SPSS versi 20. 
Sentralisasi Volume 8 ( 2 ) hal : 86 - 98 | 2019 Pengaruh Perputaran Modal Kerja, Perputaran Persedian Dan Arus Kas...

Doi (https://doi.org/10.33506/sl.v8i2.448)

Pertiwi Sriwalet

\section{Tabel 2 Pengujian Hipotesis Berganda}

Coefficients $^{\mathbf{a}}$

\begin{tabular}{|c|c|c|c|c|c|}
\hline & & Model & $\begin{array}{l}\text { Unstandardiz } \\
\text { ed } \\
\text { Coefficients }\end{array}$ & $\begin{array}{l}\text { Standardized } \\
\text { Coefficients }\end{array}$ & $\mathbf{t}$ \\
\hline \multirow[t]{4}{*}{1} & (Constant) & 3.127 & .449 & & 6.964 \\
\hline & LN_WCTO & -.563 & .042 & -1.037 & -13.529 \\
\hline & LN_ITO & -.048 & .052 & -.058 & -.940 \\
\hline & $\begin{array}{l}\text { LN_ARUSKA } \\
\text { S }\end{array}$ & -.049 & .016 & -.232 & -3.109 \\
\hline
\end{tabular}

a. Dependent Variable: LN_CR

Berdasarkan tabel diatas maka diketahui nilai-nilai sebagai berikut : Konstanta 3.127, Perputaran Modal Kerja, -0,563, Perputaran Persediaan -0,048, Arus kas -0,049. Hasil tersebut di masukkan kedalam persamaan regresi linear berganda sehingga di ketahui persamaan sebagai berikut :

\section{LnCR = 3.127- 0.563LnWCTO- 0.048 LnITO- 0.049LnCashFlow}

Nilai Konstanta $(a)=3.127$ Nilai konstanta ini menunjukkan bahwa apabila variabel bebas yaitu perputaran modal kerja, perputaran persediaan, arus kasbernilai konstan (nol), maka nilai rasio lancer sebesar 3.127satuan.

Variabel Perputaran Modal Kerja (X1) = - 0.563 Koefisien regresiini menunjukkan bahwa setiap kenaikan perputaran modal kerja sebesar 1 satuan, maka rasio lancar mengalami penurunan sebesar 0.563satuan dengan asumsi variabel lain dianggap konstan (nol).

Variabel Perputaran Persediaan $(X 2)=-0.048$ Koefisien regresiini menunjukkan bahwa setiap kenaikan perputaran persediaan sebesar 1 satuan, maka rasio lancar mengalami penurunan sebesar 0.048 satuan dengan asumsi variabel lain dianggap konstan (nol).

Variabel Arus Kas $(\mathrm{X} 3)=-0.049$ Koefisien regresiini menunjukkan bahwa setiap kenaikanarus kassebesar 1 satuan, maka rasio lancar mengalami penurunansebesar 0.049 satuan dengan asumsi variabel lain dianggap konstan (nol). 
Sentralisasi Volume 8 ( 2 ) hal : 86 - 98 | 2019 Pengaruh Perputaran Modal Kerja, Perputaran Persedian Dan Arus Kas...

Doi (https://doi.org/10.33506/sl.v8i2.448)

Pertiwi Sriwalet

Tabel 3 Hasil Pengujian Hipotesis Secara Serempak

ANOVA $^{b}$

\begin{tabular}{llrrrrr}
\hline \multicolumn{2}{l}{ Model } & \multicolumn{1}{c}{$\begin{array}{c}\text { Sum of } \\
\text { Squares }\end{array}$} & Df & Mean Square & \multicolumn{1}{c}{ F } & \multicolumn{1}{c}{ Sig. } \\
\hline $\mathbf{1}$ & Regression & 9.401 & 3 & 3.134 & 85.714 & $.000^{\mathrm{a}}$ \\
& Residual & 1.316 & 36 & .037 & & \\
& Total & 10.717 & 39 & & & \\
\end{tabular}

a. Predictors: (Constant), LN_ARUSKAS, LN_ITO,

LN_WCTO

Dependent Variable : LN_CR

Berdasarkan tabel diatas Uji signifikansi simultan / bersama-sama (uji statistik F) menghasilkan nilai $F$ hitung sebesar 85.714. Pada derajat bebas $1\left(\mathrm{df}_{1}\right)=\mathrm{k}-1=4-1=3$, dan derajat bebas $2\left(\mathrm{df}_{2}\right)=\mathrm{n}-\mathrm{k}-1=40-3-1=36$, dimana $\mathrm{n}=$ jumlah sampel, $\mathrm{k}=$ jumlah variabel. Nilai f tabel pada taraf kepercayaan signifikansi 0,05 adalah 2.87. Dengam demikian $\mathrm{F}_{\text {hitung }}=85.714>\mathrm{F}_{\text {tabel }}=2.87$ dengan tingkat signifikansi $0,000<0.05$ maka $\mathrm{H}_{\mathrm{a}}$ diterimaH $_{\mathrm{o}}$ ditolak artinya secara bersama-sama Perputaran Modal Kerja, Perputaran Persediaan, dan Arus Kas berpengaruh positif dan signifikan terhadap Rasio Lancar pada Perusahaan Makanan dan Minuman yang terdaftar di Bursa Efek Indonesia Periode 20142017.

\section{Pembahasan}

\section{Pengaruh Perputaran Modal Kerja Terhadap Rasio Lancar}

Berdasarkan hasil pengujian hipotesis secara parsial diperoleh nilai thitung perputaran modal kerja sebesar -13.529. Nilai $-\mathrm{t}_{\text {hitung }}<-\mathrm{t}$ tabel atau $-13.529<-2.02809$ dengan nilai signifikan sebesar $0.000<0,05$. Dengan demikian disimpulkan perputaran modal kerja berpengaruh negatif signifikan terhadap rasio lancar pada Perusahaan Makanan dan Minuman yang terdaftar di Bursa Efek Indonesia Periode 2014-2017.

\section{Pengaruh Perputaran Persediaan Terhadap Rasio Lancar}

Berdasarkan hasil pengujian hipotesis secara parsial (Uji-t) diperoleh nilai thitung perputaran persediaan sebesar -0.940 . Nilai $-\mathrm{t}_{\text {hitung }}>-\mathrm{t}$ tabel atau $-0.940>-2.02809$ dengan 
Sentralisasi Volume 8 ( 2 ) hal : 86 - 98 | 2019 Pengaruh Perputaran Modal Kerja, Perputaran Persedian Dan Arus Kas...

Doi (https://doi.org/10.33506/sl.v8i2.448)

Pertiwi Sriwalet nilai signifikan sebesar $0,353>0,05$. Dengan demikian disimpulkan perputaran persediaan tidak berpengaruh terhadap rasio lancer pada Perusahaan Makanan dan Minuman yang terdaftar di Bursa Efek Indonesia Periode 2014-2017.

\section{Pengaruh Arus Kas Terhadap Rasio Lancar}

Berdasarkan hasil pengujian hipotesis secara parsial diperoleh nilai thitung arus kas sebesar -3.109 . Nilai $-\mathrm{t}_{\text {hitung }}<-\mathrm{t}$ table atau $-3.109<-2.02809$ dengan nilai signifikan sebesar $0.004<0,05$. Dengan demikian disimpulkan arus kas berpengaruh negatif signifikan terhadap rasio lancar pada Perusahaan Makanan dan Minuman yang terdaftar di Bursa Efek Indonesia Periode 2014-2017.

\section{Simpulan}

Dari hasil analisis yang telah di bahas sebelumnya, maka di tarik kesimpulan sebagai berikut : (1) Hasil pengujian secara parsial menunjukkan bahwa Perputaran Modal Kerja berpengaruh negatif signifikan terhadap Rasio Lancar (2) Hasil pengujian secara parsial menunjukkan bahwa Perputaran Persediaan tidak berpengaruh terhadap Rasio Lancar (3) Hasil pengujian secara parsial menunjukkan bahwa Arus Kas berpengaruh negatif signifikan terhadap Rasio Lancar (4) Hasil pengujian secara simultan menunjukan bahwa Perputaran Modal Kerja, Perputaran Persediaan, dan Arus Kas berpengaruh positif dan signifikan terhadap Rasio Lancar.

\section{Daftar Pustaka}

Brigham, Eugene F., dan Joel F. Houston, 2012. Dasar-dasar Manajemen Keuangan. Jakarta: Salemba Empat, 2012.

Fahmi, Irham. 2016. Pengantar Manajemen Keuangan dan Teori dan Soal Jawab. Cetakan Keempat. Bandung: Alfabeta.

Harahap, Sofyan Syafri. 2015. Analisis Kritis Atas Laporan Keuangan. Cetakan Kedua Belas. Jakarta: PT.RajaGrafindo Persada.

Hery. 2015. Analisis Laporan Keuangan Pendekatan Rasio Keuangan. Cetakan Pertama. Yogyakarta: CAPS.

Jumingan. 2015. Analisis Laporan Keuangan. Cetakan Kelima. Jakarta: PT.Bumi Aksara.

Kasmir. 2012. Analisis Laporan Keuangan. Jakarta: PT.RajaGrafindo Persada

Munawir. 2007. Analisa Laporan Keuangan. Cetakan Keempat Belas. Yogyakarta: Liberty Yogyakarta. 
Sentralisasi Volume 8 ( 2 ) hal : 86 - 98 | 2019 Pengaruh Perputaran Modal Kerja, Perputaran Persedian Dan Arus Kas...

Doi (https://doi.org/10.33506/sl.v8i2.448)

Pertiwi Sriwalet

Riyanto, Bambang. 2009. Dasardasar Pembelanjaan Perusahaan. Cetakan Keenam. Yogyakarta: BPFE.

Sartono, Agus. 2010. Manajemen Keuangan, Teori dan Aplikasi. Ed 4. Yogyakarta: BPFE

Sawir, Agnes. 2015. Analisis Kinerja Keuangan Dan Perencanaan Perusahaan. Cetakan Kesepuluh. Jakarta: PT.Gramedia Pustaka Utama.

Syamsuddin, Lukman. 2011. Manajemen Keuangan Perusahaan. Cetakan Kesebelas. Jakarta: PT.RajaGrafindo Persada.

Van Horne, James, John M.Wachowicz Jr. 2013. Prinsip-Prinsip Manajemen Keuangan. Jakarta: Salemba Empat 